\title{
The Effect of Different Hemostatic Systems on the Injury of the External Branch of the Superior Laryngeal Nerve in Thyroidectomy
}

\author{
Tiroidektomi Ameliyatında Kullanılan Farklı Damar Kapama Sistemlerinin Süperior \\ Laringeal Sinirin Eksternal Dalı Yaralanması Üzerine Etkisi
}

(D) Volkan Özben11, (D) Recep Özgültekin1 ${ }^{1}$, (D) Nurten Adatepe², (D) Asım Kaytaz³

1istanbul University-Cerrahpaşa Faculty of Medicine, Department of General Surgery, istanbul, Turkey

2istanbul University-Cerrahpaşa Faculty of Medicine, Department of Neurology, istanbul, Turkey

3istanbul University-Cerrahpașa Faculty of Medicine, Department of Otorhinolaryngology, İstanbul, Turkey

\section{ABSTRACT}

Introduction: Vessel-sealing and ultrasonic coagulation systems that provide rapid and effective hemostasis are widely used in thyroid surgery. An important disadvantage of these systems is injury to the neighboring anatomical structures by thermal damage. However, data on injury to the external branch of the superior laryngeal nerve is limited. The aim of this study was to evaluate the effect of different vascular closure systems on this nerve injury in thyroidectomy.

Methods: A total of 45 patients who underwent thyroidectomy for benign thyroid disease between October 2008 and February 2009 were included in the study. Patients were randomized and divided into three groups, each consisting of 15 patients. Systems used were vessel-sealer in the first group, harmonic scalpel in the second group and conventional suture ligation technique in the third group. Laryngeal electromyography findings and voice complaints were compared.

Results: There were 37 female (82\%) and 8 male patients.

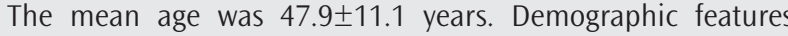
and surgical procedures were statistically similar in all groups $(p>0.05)$. The control electromyography of 84 nerves with preoperatively confirmed normal findings showed that three $(10.7 \%)$ of the 28 nerves in the vessel sealer group, two (7.1\%) of the 28 nerves in the harmonic scalpel group, and two (7.1\%) of the 28 nerves in the suture ligation group had complete or partial nerve injury $(p>0.05)$. No significant difference was found between the groups in terms of voice complaints $(p>0.05)$.

Conclusion: Compared to the conventional suture ligation technique, the use of vascular closure devices does not increase the risk of injury to the external branch of the superior laryngeal nerve.

Keywords: Electromyography, external branch of the superior laryngeal nerve, nerve injury, thyroidectomy, vascular closure systems $\ddot{0 ̈ Z}$

Amaç: Hızlı ve etkin bir şekilde hemostaz sağlayan damar mühürleyici ve ultrasonik koagülasyon sistemleri tiroid cerrahisinde yaygın bir şekilde kullanılmaktadır. Bu sistemlerin bir dezavantajı termal hasar yolu ile komşu anatomik yapılara zarar verebilmesidir. Ancak süperior laringeal sinirin eksternal dalının yaralanması ile ilgili veriler sınırlıdır. Bu çalışmanın amacı tiroidektomi ameliyatında kullanılan farklı damar kapama sistemlerinin bu sinir yaralanması üzerine olan etkisini değerlendirmektir.

Yöntemler: Çalışmaya Ekim 2008ile Şubat 2009 tarihleri arasında selim tiroid hastalığı nedeni ile tiroidektomi ameliyatı yapılan toplam 45 hasta dahil edildi. Hastalar randomize edilerek her biri 15'er hastadan oluşan toplam üç gruba ayrıldı. Ameliyatta ilk grupta damar mühürleyici, ikinci grupta harmonik kesici ve üçüncü grupta klasik sütür ile bağlama tekniği kullanıldı. Hastaların laringeal elektromiyografi bulguları ve ses șikayetleri karșılaștırıldı.

Bulgular: Hastaların 37'si kadın (\%82), 8'i erkek ve yaş ortalaması $47,9 \pm 11,1$ yıl idi. Demografik özellikler ve cerrahi ișlemler tüm gruplarda istatistiksel olarak benzer bulundu $(p>0,05)$. Ameliyat öncesi elektromiyografi bulguları normal olan 84 adet sinirin kontrol incelemesinde damar mühürleyici grubunda 28 sinirin 3'ünde $(\% 10,7)$, harmonik kesici grubunda 28 sinirin 2 'sinde $(\% 7,1)$ ve klasik sütür ile bağlama grubunda 28 sinirin 2'sinde $(\% 7,1)$ tam veya parsiyel sinir yaralanması mevcuttu $(p>0,05)$. Ses șikayetleri açısından gruplar arasında anlamlı fark saptanmadı $(p>0,05)$.

Sonuç: Damar kapama cihazlarının kullanımı klasik sütür bağlama tekniği ile karşılaștırıldığında, süperior laringeal sinirin eksternal dalı yaralanması riskini artırmadığı görülmektedir.

Anahtar Kelimeler: Elektromiyografi, süperior laringeal sinirin eksternal dalı, sinir yaralanması, tiroidektomi, damar kapama sistemleri
Address for Correspondence/Yazıșma Adresi: Volkan Özben, İstanbul University-Cerrahpașa Faculty of Medicine, Department of General Surgery, İstanbul, Turkey

Phone: +90 5346484678 E-mail: volkanozben@yahoo.co.uk ORCID ID: orcid.org/0000-0002-9620-5080

Cite this article as/Atıf: Özben V, Özgültekin R, Adatepe N, Kaytaz A. The Effect of Different Hemostatic Systems on the Injury of the External Branch of the Superior Laryngeal Nerve in Thyroidectomy. İstanbul Med J 2019; 20(2):119-24

(c) Copyright 2019 by the Istanbul Training and Research Hospital/Istanbul Medical Journal published by Galenos Publishing House.

(C) Telif Hakkı 2019 İstanbul Ĕgitim ve Araștırma Hastanesi/Istanbul Tıp Dergisi, Galenos Yayınevi tarafından basılmıștır.
Received/Geliș Tarihi: 31.01.2018 Accepted/Kabul Tarihi: 16.10.2018 


\section{Introduction}

Thyroidectomy requires good anatomic exposure, careful dissection and adequate hemostasis. The principles of safe and effective thyroid surgery were standardized by Emil Theodor Kocher and Theodor Billroth between 1873-1883, and the mortality rate decreased to less than $5 \%$ thanks to this technique that reduces bleeding with the ligation of the arteries of the thyroid gland (1). Although this principle is still valid, morbidity rates have decreased with the increase in experience and the use of modern techniques.

In recent years, alternatives to electrocoagulation have been developed and been widely used in thyroid surgery, such as bipolar vessel sealer and ultrasonic cutter, which provide rapid and effective hemostasis (24). However, a disadvantage of these systems is that they can damage adjacent anatomical structures by direct or lateral thermal spread (5-7). These adjacent structures include the external branch of the superior laryngeal nerve (EBSLN), and in particular, injury to the nerve occurs during the dissection of the upper pole of the thyroid gland $(8,9)$. EBSLN is the only nerve that innervates the cricothyroid muscle, which is the tensor of the vocal cords, and its injury may lead to hoarseness, loss of strength of the voice, vocal fatigue and inability to achieve high pitch tasks $(10,11)$.

Although there are many studies in the literature on the effect of vascular closure systems on postoperative complications in thyroid surgery, there is little data on EBSLN injury (12). Therefore, in this study, we aimed to evaluate the effect of different vascular closure systems on iatrogenic EBSLN injury in patients undergoing thyroidectomy.

\section{Methods}

For the study, approval was obtained from İstanbul University, Cerrahpaşa Faculty of Medicine, Ethics Committee of Medical, Surgical and Pharmaceutical Research (decision no: 35792). A total of 45 patients who underwent thyroidectomy at the Endocrine Surgery Service of istanbul University, Cerrahpașa Faculty of Medicine between October 2008 and February 2009 were included in the study. Patients who had undergone previous thyroid surgery, patients with recurrent disease or thyroid cancer, and patients with voice complaints prior to surgery were excluded from the study. All patients were informed about the procedures and written informed consent was obtained.

The patients were randomized by computer program and divided into three equal groups, each consisting of 15 patients. All patients underwent thyroid function tests, thyroid ultrasonography, scintigraphy or fine needle aspiration biopsy for preoperative diagnosis. Standard bilateral thyroidectomy (total, near-total or subtotal) was performed. All patients were operated by the same surgical team. LigaSure Precise (Valleylab Corp., Tyco Healthcare Group LP, Colorado, US) was used for vascular ligation in the first group (LigaSure group) (Figure 1), Ultracision" harmonic scalpel (Ethicon Endo-Surgery, Ohio, US) in the second group (Ultracision group) (Figure 2), and conventional suture ligation technique in the third group (suture group) (Figure 3).

Under general anesthesia, the patient was placed in a supine position with the neck extended. After proper skin cleansing, Kocher's collar incision was made, and upper and lower skin flaps were developed.
Thyrohyoid and sternohyoid muscles were divided vertically in the midline, and surgical field was entered. The right lobe of the thyroid was dissected free from the middle thyroid vein. The superior parathyroid gland was identified and preserved. The superior thyroid artery and vein were dissected and ligated from the level close to the thyroid capsule. In the meantime, no dissection was performed to

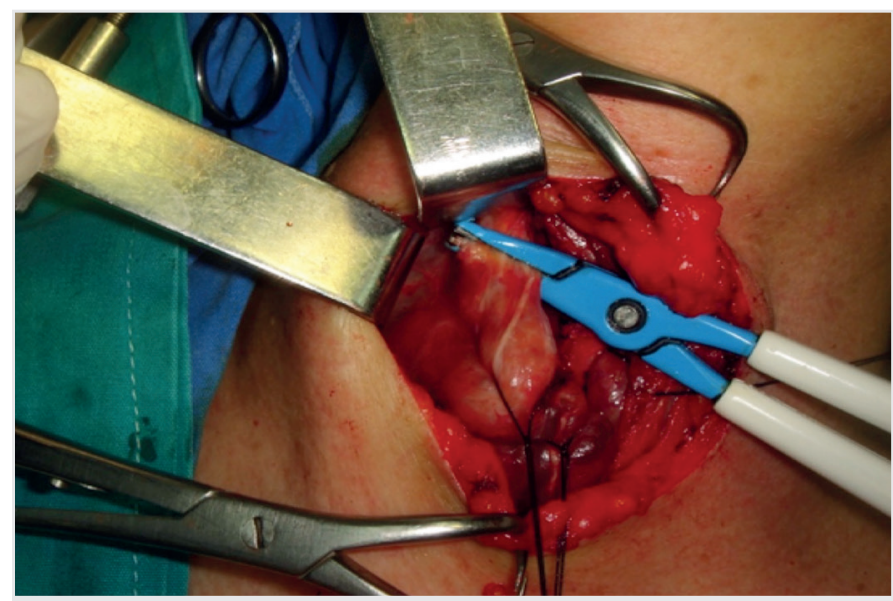

Figure 1. Release of the upper pole of the right thyroid gland with LigaSure Precise $^{\circledR}$

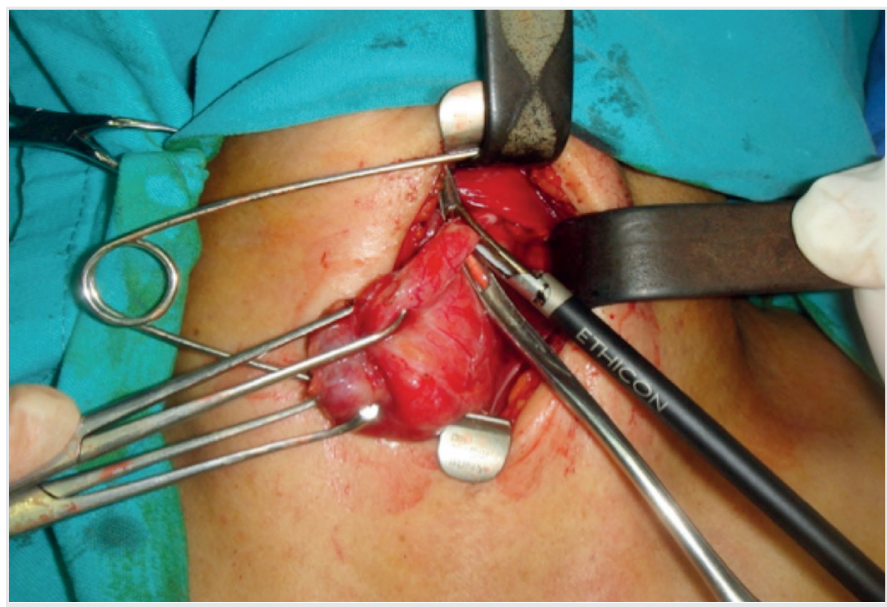

Figure 2. Release of the upper pole of the left thyroid gland with Ultracision $^{\circledR}$

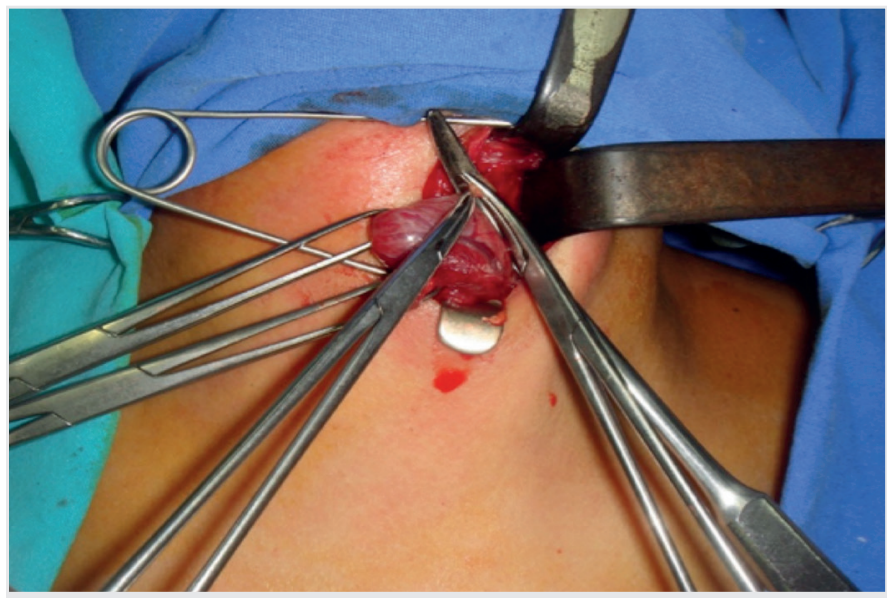

Figure 3. Release of the upper pole of the left thyroid gland with conventional suture ligation technique 
reveal the EBSLN.The right recurrent laryngeal nerve was preserved in the anterolateral tracheal area. Subsequently, the inferior pole vessels were ligated by preserving inferior parathyroid gland. The contralateral thyroid lobe was removed in a similar manner. Thyroidectomy procedure was completed with removal of the specimen along with the isthmus. Following hemostasis, a drain was placed. The midline muscles and skin were closed and the operation was terminated.

The function of EBSLN was evaluated by laryngeal electromyography (EMG). Recordings were performed before and after surgery in all patients, and bilateral cricothyroid muscles were examined. Preoperative muscular pathologies were investigated and repeated after one month because of abnormal spontaneous discharges. Before the control EMG, the patients were questioned in terms of phonation disorders (hoarseness, loss of strength of the voice, vocal fatigue and inability to achieve high pitch tasks). Neuropack MEB-9102K (Nihon Kohden, Tokyo, Japan) device was used for laryngeal EMG. Recordings were performed

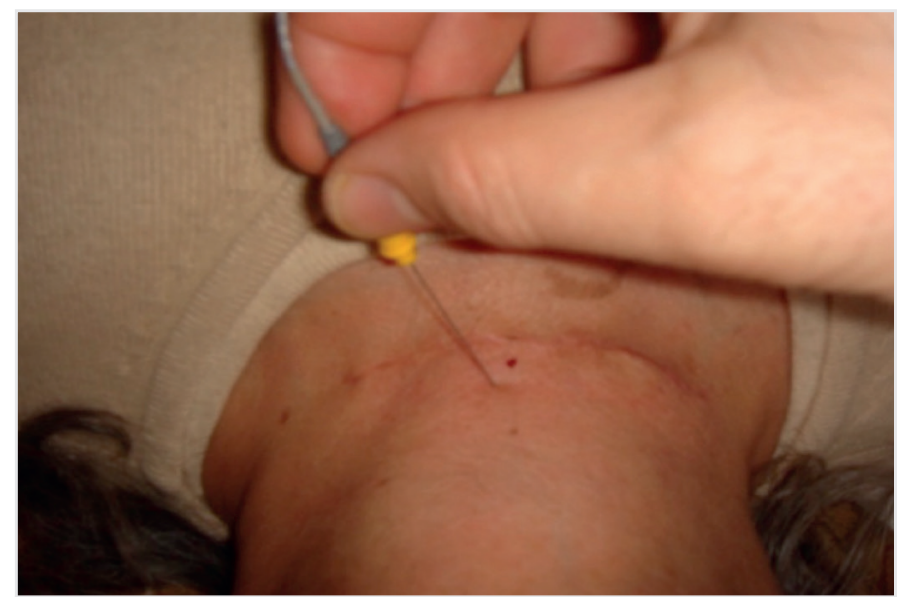

Figure 4. Insertion of the needle electrode into the cricothyroid muscle for the evaluation of superior laryngeal nerve function in a patient who underwent postoperative electromyography
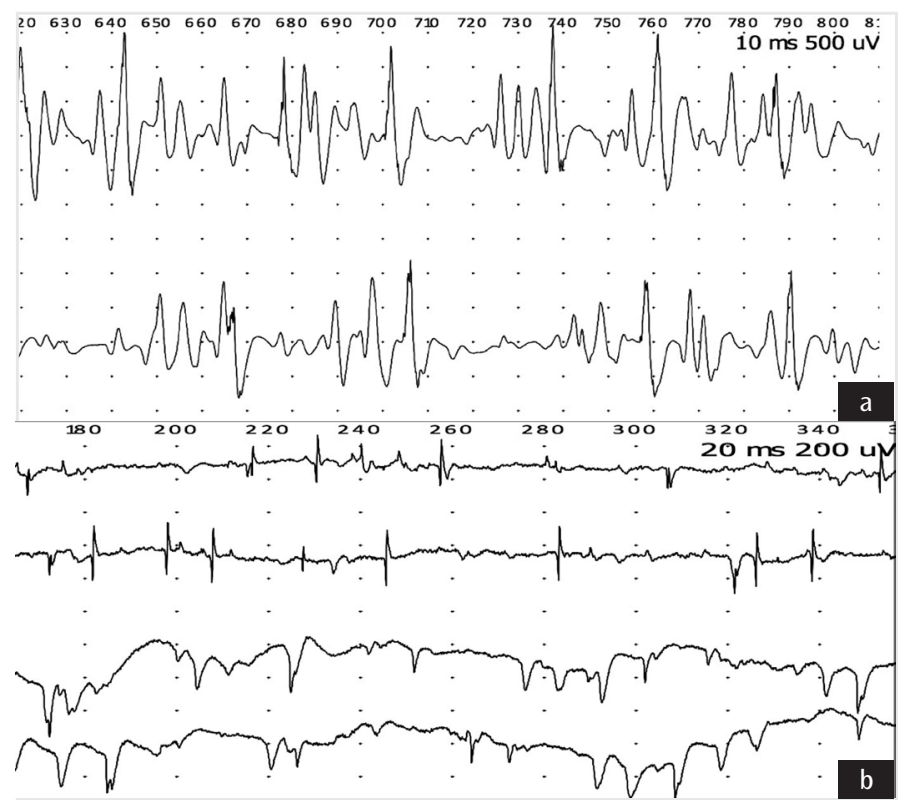

Figure 5. (a) Normal motor unit action potential pattern and (b) denervation pattern in laryngeal cricothyroid muscle electromyography with concentric bipolar needle electrodes (size: 50x45 mm) (Myoline, Spes Medica, Italy). The ground electrode was placed in the neck area far from the needle entrance site and the patient was placed in the supine position. Local anesthetic agent or premedication was not performed because the procedure was relatively painless and anesthetic agents could cause artifact in action potentials in the cricothyroid muscle. A needle electrode was inserted into the cricothyroid muscle to evaluate the function of EBSLN. For this purpose, the neck of the patient was extended and the needle electrode was inserted into the cricothyroid membrane in the midline and directed 30-45 degrees laterally (Figure 4). After making sure that the tip of the electrode was in the muscle by phonation, the input activity of the needle, the presence of spontaneous activity at rest, the shape, duration and amplitudes of the motor unit action potentials during active contraction of the muscle were recorded via an audiomonitor and oscilloscope. Wave morphology was evaluated by the same neurologist in terms of EBSLN injury.

Demographic data, pathological diagnoses, surgical procedure, EMG findings and vocal complaints that occurred within one month after surgery were recorded in the follow up forms prepared for each patient.

\section{Statistical Analysis}

Data were analyzed by using SPSS 11 (SPSS Inc., Chicago, IL, USA), and comparisons between groups were performed using ANOVA post hoc Tukey and chi-square tests. Values were given as mean \pm standard deviation. $\mathrm{P}<0.05$ was considered statistically significant.

\section{Results}

Of the 45 patients included in the study, 37 were female (82\%) and 8 were male (18\%). The mean age of the patients was $47.9 \pm 11$ (range: 21-68) years. Demographic data and clinical findings of the patients are presented in Table 1 . The rate of female patients was $87 \%$ in the LigaSure group and $80 \%$ in the Ultracision and suture groups. Histopathological examination revealed no malignancy. There was no statistically significant difference between the demographic data and the surgeries performed $(p>0.05)$.

The distribution of preoperative and postoperative EMG findings of groups is given in Table 2. When all groups were taken into account, a total of five EBSLN had pathologic EMG findings in the preoperative period. These were unilateral weak activity in one patient and unilateral activity loss in one patient in the LigaSure group, unilateral activity loss in one patient and unilateral neurogenic involvement in one patient in the Ultracision group, and unilateral weak activity in one patient in the suture group. In addition, unilateral EBSLN function could not be evaluated in one patient in the suture group because of postoperative technical failure. As a result, a total of 84 nerves were included in the statistical analysis, except for one nerve that could not be evaluated due to technical failure and five nerves with preoperative pathology in the EMG.

While EMG findings were normal in the preoperative period, one patient (6.7\%) in the LigaSure group and one patient (6.7\%) in the suture group had a unilateral cricothyroid muscle denervation pattern in the postoperative period (Figure 5). In addition, two patients (13.3\%) in the LigaSure group, two patients (13.3\%) in the Ultracision group 
and one patient $(6.7 \%)$ in the suture group developed unilateral weak action potential patterns in the postoperative period despite normal preoperative EMG findings. Denervation and weak action potential patterns were consistent with EBSLN injury (Table 2).

In the postoperative control EMG of 84 EBSLNs with preoperative normal EMG findings, pathology was detected in three of the 28 EBSLN in the LigaSure group, two of the 28 EBSLN in the Ultracision group, and two of the 28 EBSLN in the suture group. There was no statistical difference between the groups $(p=0.61$ ) (Table 3 ).

Postoperative vocal complaints were present in three patients in the LigaSure group, three patients in the Ultracision group and two patients in the suture group. No significant difference was found between groups in terms of vocal complaints ( $p=0.60)$ (Table 3 ).

\section{Discussion}

Thyroidectomy is one of the common surgeries in general surgery clinics. Although the principles of surgery have not changed much, new devices have been put into use with developing technology in order to make hemostasis faster and safer. LigaSure ${ }^{\circledR}$, also known as electrothermal vessel sealing system, is a dissection and coagulation device developed in recent years. Ultracision ${ }^{\circledR}$ provides simultaneous coagulation and cutting with ultrasonic energy, and also has achieved a place in thyroid surgery in a short time (2-4). However, a significant disadvantage of these systems is that they may cause nerve injuries in thyroid surgery depending on the energy used (5-7). The results obtained in this study that specifically analyzed EBSLN injury showed that the use of these vascular closure systems in thyroidectomy surgery did not increase this complication compared to the classical suture ligation technique.

In the studies comparing vascular closure systems and conventional suture technique in the literature, complications such as postoperative hemorrhage, recurrence laryngeal nerve injury and hypoparathyroidism were evaluated in the morbidity parameters $(3,4,6,7)$, and data on EBSLN injury were insufficient. The only study in this regard is a prospective randomized study by Arslan et al. (12) that compares the harmonic scalpel with conventional suture ligation technique in thyroidectomy.

Table 1. The distribution of demographic characteristics and surgical procedures according to groups

\begin{tabular}{|l|l|l|l|l|}
\hline & LigaSure group & Ultracision group & Suture group & p \\
\hline Age, years \pm SD & $44.4 \pm 11$ & $46.6 \pm 12$ & $50.8 \pm 11$ & 0.4 \\
\hline Female/male, $\mathrm{n}(\%)$ & $13 / 2(87)$ & $12 / 3(80)$ & $12 / 3(80)$ & 0.6 \\
\hline Surgery, $\mathrm{n}(\%)$ & & & 0.3 \\
\hline Total thyroidectomy & $10(67)$ & $7(47)$ & $10(67)$ & - \\
\hline Near-total/subtotal thyroidectomy & $5(33)$ & $8(53)$ & $5(33)$ & - \\
\hline
\end{tabular}

SD: standard deviation

Table 2. Distribution of electromyography findings according to groups

\begin{tabular}{|c|c|c|c|c|c|c|}
\hline & \multicolumn{2}{|l|}{ LigaSure group } & \multicolumn{2}{|c|}{ Ultracision group } & \multicolumn{2}{|l|}{ Suture group } \\
\hline & Preoperative & Postoperative & Preoperative & Postoperative & Preoperative & Postoperative \\
\hline \multicolumn{7}{|l|}{ EMG findings, $\mathrm{n}(\%)^{*}$} \\
\hline Bilaterally normal & $13(87)$ & $11(73)$ & $13(87)$ & $12(80)$ & $14(93)$ & $11(73)$ \\
\hline Unilateral weak activity & $1(7)$ & $3(20)$ & $0(0)$ & $2(13)$ & $1(7)$ & $2(13)$ \\
\hline Unilateral activity loss & $1(7)$ & $0(0)$ & $1(7)$ & $0(0)$ & $0(0)$ & $0(0)$ \\
\hline Unilateral neurogenic involvement & $0(0)$ & $0(0)$ & $1(7)$ & $1(7)$ & $0(0)$ & $0(0)$ \\
\hline Unilateral denervation & $0(0)$ & $1(7)$ & $0(0)$ & $0(0)$ & $0(0)$ & $1(7)$ \\
\hline Technical failure & $0(0)$ & $0(0)$ & $0(0)$ & $0(0)$ & $0(0)$ & $1(7)$ \\
\hline \multicolumn{7}{|l|}{ EMG findings, $\mathrm{n}(\%)^{* *}$} \\
\hline Normal & $28(93)$ & $26(87)$ & $28(93)$ & $27(90)$ & $29(97)$ & $26(87)^{* * * *}$ \\
\hline Pathologic & $2(7)$ & $4(13)$ & $2(7)$ & $3(10)$ & $1(3)$ & $3(10)$ \\
\hline
\end{tabular}

Table 3. Comparison of superior laryngeal nerve injury and postoperative phonation disorders among groups

\begin{tabular}{|l|l|l|l|}
\hline & LigaSure group & Ultracision group & Suture group \\
\hline Surgical SLN injury, SLN number (\%) & $3 / 28(10.7)$ & $2 / 28(7.1)$ & $2 / 28(7.1)$ \\
\hline Phonation disorder, number of patients & 2 & 2 & 2 \\
\hline SLN: superior laryngeal nerve, SD: standard deviation & & 0.6 \\
\hline
\end{tabular}


A total of 206 patients were included in this study, and temporary and permanent EBSLN injuries were detected in four (4\%) and three (\%) patients in the harmonic scalpel group and in two (1.9\%) and two patients (1.9\%) in the other group, respectively. No significant difference was found between the groups. The authors concluded that the use of a harmonic scalpel was safe for EBSLN injury.

The superior laryngeal nerve is separated from the vagus around the skull base; it descends from the medial of the carotid vessels and is divided into two branches as internal and external at the level of hyoid bone. The internal branch provides the sensation of epiglottis and larynx. EBSLN runs with superior thyroid vessels, and provides motor innervation of the cricothyroid muscle and determines the style of the voice by tensing the vocal cords $(8,10,11)$. As a result of trauma to the nerve, the vocal cord in that side becomes flask and this creates difficulty in phonation. This is especially important for those who practice their profession using their voice continuously (teacher, announcer, singer, etc.) $(8,11)$.

Vocal changes related to EBSLN injury were first described by Moran and Castro (13) in 1951, and later Cernea et al. (14) reported the anatomical classification of the different localizations of the nerve and reported high-risk location for surgical injury. According to this classification, EBSLN has a high-risk of injury during the release of thyroid upper pole. Later, Selvan et al. (15) described a new classification system on the anatomical localization of the nerve accompanied by EMG findings by performing EBSLN monitoring. According to this classification, the area with the highest risk of injury is defined as the area $1 \mathrm{~cm}$ superiorposterior of the artery before entering the thyroid gland. In the light of this anatomical information, some authors stated that the EBSLN should be explored directly or by intraoperative nerve monitoring before ligation of the artery (16-18), while others stated that even careful dissection in this area could damage the nerve $(15,19)$. In our study, EBSLN was not visualized in none of the patients as it was thought to increase the risk of nerve injury and dissection was performed close to the capsule of the thyroid gland.

The fact that the vocal change due to EBSLN injury in thyroid surgery is not noticed by both the patient and the surgeon, or the requirement of detailed analyzes in order to reveal the pathology even if it is noticed shows why less attention is given to this nerve than the recurrent laryngeal nerve. Recurrent laryngeal nerve injury can be detected by simple diagnostic methods such as indirect laryngoscopy or fiberoptic examination, EBSLN injury requires the use of more advanced techniques such as laryngeal videostroboscopy, spectrographic analysis and laryngeal EMG. Among these techniques, the more invasive and time-consuming cricothyroid muscle EMG is the most accurate diagnostic method $(9,20)$. The risk of iatrogenic partial or complete EBSLN injury varies between $0 \%$ and $6 \%$ after thyroidectomy and this rate increases up to $60 \%$ when EMG is performed $(12,14,18,21)$.

In our study, the muscle denervation pattern detected in one patient in the LigaSure group and one patient in the suture group in the postoperative period is the most objective finding indicating complete nerve injury. This finding was not observed in any patient in the Ultracision group. In addition, weak action potentials detected in two patients in the LigaSure and Ultracision groups and one patient in the suture group indicate a mild axonal injury, namely partial nerve injury. There was no difference in EBSLN injury when all groups were compared.

Although surgical iatrogenic injuries are the most frequent, viral infectious diseases, trauma, peripheral neuropathies and some motor neuron diseases may cause loss of function in EBSLN and clinical symptoms may be subclinical (22). In our study, preoperative EMG was performed in all patients in order to determine if the postoperative nerve damage was iatrogenic or was an already existing pathological condition. When all study groups were considered, five patients had pathologic EMG findings in the preoperative period. If EMG is not performed in the preoperative period in such patients, the pathological EMG findings that may develop after surgery may lead to misinterpretations in terms of nerve damage. Similarly, the phonation disorders that can occur in patients with no obtained cricothyroid muscle activity in preoperative EMG, but with normal postoperative findings cannot be attributed to EBSLN injury. This suggests that the anatomical localization of the muscle may have changed due to the enlarged thyroid tissue. In our study, the right cricothyroid muscle could not be localized in one patient in the suture group. An additional interpretation could not be made for this muscle, which suggests that anatomical localization is impaired due to the displacement secondary to surgery.

\section{Study Limitations}

Lack of EMG control in the long term after surgery is an important limitation of our study. In laryngeal nerve paralysis, EMG findings may vary according to the severity and duration of nerve damage. In neuropraxia, neurogenic involvement that improves in a few weeks and decreased activity are observed in cricothyroid muscle. While denervation and reinnervation are seen in axonotmesis, denervation and loss of motor unit as well as inability to reinnervarte are observed in neurotmesis (23). For this reason, EMG should be repeated after 6 or 12 months in order to monitor the course of axon damage in the nerve and to follow up the reinnervation in cases with mild nerve damage and denervation. In addition, the lack of evaluation of the vocal cords by laryngoscopic examination in order to reveal whether the cause of vocal complaints is EBSLN injury or any recurrent laryngeal nerve injury is another limitation of the study.

\section{Conclusion}

In this study, it was found that hemostatic vascular closure systems did not increase the risk of EBSLN injury in thyroid surgery compared to the conventional suture ligation technique. The choice of the device to be used should be made by considering factors such as experience and cost.

Ethics Committee Approval: For the study, approval was obtained from İstanbul Universitiy-Cerrahpaşa Faculty of Medicine Ethics Committee of Medical, Surgical and Pharmaceutical Research (decision no: 35792).

Informed Consent: All patients were informed about the procedures and written informed consent was obtained.

Peer-review: Internally peer-reviewed. 
Author Contributions: Concept - V.Ö., R.Ö.; Design - V.Ö., R.Ö., N.A.; Supervision - R.Ö., N.A., A.K; Resources - V.Ö., N.A., A.K.; Data Collection and/or Processing - V.Ö.; Analysis and/or Interpretation - V.Ö., R.Ö.; Literature Search - V.Ö., R.Ö.; Writing Manuscript - V.Ö., R.Ö., N.A., A.K.; Critical Review - N.A.,R.Ö., A.K.

Conflict of Interest: The authors have no conflict of interest.

Financial Disclosure: The authors did not receive financial support for this study.

\section{References}

1. Becker WF. Presidential address: pioneers in thyroid surgery. Ann Surg 1977; 185: 493-504.

2. Erbil Y, Sümer A, Sari S, Ercetin C, Issever H, Ozarmagan S. Novel hemostatic devices in thyroid surgery: are they necessary in every patient performing thyroidectomy? Surg Technol Int 2010; 19: 85-90.

3. Saint Marc 0 , Cogliandolo A, Piquard A, Famà F, Pidoto RR. LigaSure vs clampand-tie technique to achieve hemostasis in total thyroidectomy for benign multinodular goiter: a prospective randomized study. Arch Surg 2007; 142: $150-6$

4. Yildirim O, Umit T, Ebru M, Bulent U, Belma K, Betul B, et al. Ultrasonic harmonic scalpel in total thyroidectomies. Adv Ther 2008; 25: 260-5.

5. Adamczewski Z, Król A, Kałuźna-Markowska K, Brzeziński J, Lewiński A, Dedecjus M. Lateral spread of heat during thyroidectomy using different haemostatic devices. Ann Agric Environ Med 2015; 22: 491-4.

6. Yao HS, Wang Q, Wang WJ, Ruan CP. Prospective clinical trials of thyroidectomy with LigaSure vs conventional vessel ligation: a systematic review and metaanalysis. Arch Surg 2009; 144: 1167-74.

7. Zanghì A, Cavallaro A, Di Vita M, Cardi F, Di Mattia P, Piccolo G, et al. The safety of the Harmonic ${ }^{\circledR}$ FOCUS in open thyroidectomy: a prospective, randomized study comparing the Harmonic ${ }^{\circledR}$ FOCUS and traditional suture ligation (knot and tie) technique. Int J Surg 2014; 12 Suppl: S132-5.

8. Kochilas X, Bibas A, Xenellis J, Anagnostopoulou S. Surgical anatomy of the external branch of the superior laryngeal nerve and its clinical significance in head and neck surgery. Clin Anat 2008; 21: 99-105.

9. Potenza AS, Araujo Filho VJF, Cernea CR. Injury of the external branch of the superior laryngeal nerve in thyroid surgery. Gland Surg 2017; 6: 552-62.

10. Furlan JC, Brandão LG, Ferraz AR, Rodrigues AJ. Surgical anatomy of the extralaryngeal sspect of the superior laryngeal nerve. Arch Otolaryngol Head Neck Surg 2003; 129: 79-82.

11. Seven H, Alkan Z, Cakir BO, Sam B, Uslu B, Turgut S. The topographical anatomy of the external branch of the superior laryngeal nerve and its importance in thyroid surgery: A cadaver study. Kulak Burun Bogaz Ihtis Derg 2003; 11: 161-5.

12. Arslan K, Erenoglu B, Dogru O, Ovet G, Turan E, Atay A, et al. Is the superior laryngeal nerve really safe when using harmonic focus in total thyroidectomy? A prospective randomized study. Asian J Surg 2018; 41: 222-8.

13. Moran RE, Castro AF. The superior laryngeal nerve in thyroid surgery. Ann Surg 1951; 134: 1018-21.

14. Cernea CR, Ferraz AR, Nishio S, Dutra A Jr, Hojaij FC, Santos LRM. Surgical anatomy of the external branch of the superior larengeal nerve. Head and Neck 1992; 164: 634-9

15. Selvan B, Babu S, Paul MJ, Abraham D, Samuel P, Nair A. Mapping the compound muscle action potentials of cricothyroid muscle using electromyography in thyroid operations: a novel method to clinically type the external branch of the superior laryngeal nerve. Ann Surg 2009; 250: 293-300.

16. Barczyński M, Randolph GW, Cernea C; International Neural Monitoring Study Group in Thyroid and Parathyroid Surgery. International survey on the identification and neural monitoring of the EBSLN during thyroidectomy. Laryngoscope 2016; 126: 285-91.

17. Masuoka H, Miyauchi A, Higashiyama T, Yabuta T, Fukushima M, Ito Y, et al. Prospective randomized study on injury of the external branch of the superior laryngeal nerve during thyroidectomy comparing intraoperative nerve monitoring and a conventional technique. Head Neck 2015; 37: 145660 .

18. Uludag M, Aygun N, Kartal K, Citgez B, Besler E, Yetkin G, et al. Contribution of intraoperative neural monitoring to preservation of the external branch of the superior laryngeal nerve: a randomized prospective clinical trial. Langenbecks Arch Surg 2017; 402: 965-76.

19. Bellantone R, Boscherini M, Lombardi CP, Bossola M, Rubino F, De Crea C, et al. Is the identification of the external branch of the superior laryngeal nerve mandatory in thyroid operation? Results of a prospective randomized study. Surgery 2001; 130: 1055-9.

20. Sulica L. The superior laryngeal nerve: function and dysfunction. Otolaryngol Clin North Am 2004; 37: 183-201.

21. Jansson S, Tisell LE, Hagne I, Sanner E, Stenborg R, Svensson P. Partial superior laryngeal nerve (SLN) lesions before and after thyroid surgery. World J Surg 1988; 12: 522-7.

22. Dursun G, Demireller A, Koçak I, Selçuki D, Acar A, Demirci S. Laringeal elektromiyografi. Baș ve Boyun Damar Cerrahisi Dergisi 1995; 3: 253-61.

23. Ertekin C. Sentral ve Periferik EMG. Anatomi-Fizyoloji-Klinik. META Basım, İzmir: 2006; 571-9. 